\title{
Assessment of gene expression of intracellular calcium channels, pumps and exchangers with epidermal growth factor-induced epithelial-mesenchymal transition in a breast cancer cell line
}

\author{
Felicity M Davis ${ }^{1}$, Michelle T Parsonage ${ }^{1}$, Peter J Cabot ${ }^{1}$, Marie-Odile Parat ${ }^{1}$, Erik W Thompson ${ }^{2,3}$, \\ Sarah J Roberts-Thomson ${ }^{1}$ and Gregory R Monteith ${ }^{*}$
}

\begin{abstract}
Background: Epithelial-mesenchymal transition (EMT) is a process implicated in cancer metastasis that involves the conversion of epithelial cells to a more mesenchymal and invasive cell phenotype. In breast cancer cells EMT is associated with altered store-operated calcium influx and changes in calcium signalling mediated by activation of cell surface purinergic receptors. In this study, we investigated whether MDA-MB-468 breast cancer cells induced to undergo EMT exhibit changes in mRNA levels of calcium channels, pumps and exchangers located on intracellular calcium storing organelles, including the Golgi, mitochondria and endoplasmic reticulum (ER).

Methods: Epidermal growth factor (EGF) was used to induce EMT in MDA-MB-468 breast cancer cells. Serum-deprived cells were treated with EGF $(50 \mathrm{ng} / \mathrm{mL})$ for $12 \mathrm{~h}$ and gene expression was assessed using quantitative RT-PCR.

Results and conclusions: These data reveal no significant alterations in mRNA levels of the Golgi calcium pump secretory pathway calcium ATPases (SPCA1 and SPCA2), or the mitochondrial calcium uniporter (MCU) or $\mathrm{Na}^{+} / \mathrm{Ca}^{2+}$ exchanger (NCLX). However, EGF-induced EMT was associated with significant alterations in mRNA levels of specific ER calcium channels and pumps, including (sarco)-endoplasmic reticulum calcium ATPases (SERCAs), and inositol 1,4,5-trisphosphate receptor $\left(\mathrm{P}_{3} \mathrm{R}\right)$ and ryanodine receptor (RYR) calcium channel isoforms. The most prominent change in gene expression between the epithelial and mesenchymal-like states was RYR2, which was enriched 45 -fold in EGF-treated MDA-MB-468 cells. These findings indicate that EGF-induced EMT in breast cancer cells may be associated with major alterations in ER calcium homeostasis.
\end{abstract}

Keywords: Breast cancer calcium, EMT, IP ${ }_{3} R$, RYR, SERCA, SPCA, MCU, NCLX

\section{Background}

EMT facilitates cancer cell invasion and metastasis formation, and has also been linked to the acquisition of a stem cell-like phenotype, anchorage-independent growth and chemoresistance in cancer cell lines and clinical samples [1-4]. The phenotypic changes associated with EGF-induced EMT are well characterised in the human

\footnotetext{
* Correspondence: gregm@uq.edu.au

'School of Pharmacy, The University of Queensland, Brisbane, QLD 4072, Australia

Full list of author information is available at the end of the article
}

breast cancer cell line MDA-MB-468, and include changes in cell morphology; increased expression of the transcription factor Twist and the intermediate filament protein vimentin; and reduced E-cadherin expression following chronic EGF treatment [5-8]. In addition, EGF-induced EMT in MDA-MB-468 breast cancer cells has been linked to altered plasma membrane calcium influx $[6,7,9]$.

Increases in cytosolic calcium may occur via calcium entry through calcium permeable plasma membrane channels, including transient receptor potential (TRP),

\section{Biomed Central}


voltage-gated and store-operated calcium channels, or due to the release of calcium from internal stores [10-12]. Calcium signals arising via influx or storerelease have distinct spatiotemporal profiles, modes of activation, and cellular responses [13]. These two processes often occur in parallel, for example calcium store release triggering store-operated calcium influx [14], and calcium influx via specific plasma membrane calcium channels potentially causing calcium release from the ER via calcium-induced calcium release (CICR) [15]. Mitochondrial calcium buffering may also alter the nature of cytosolic calcium responses [16-19]. Thus changes in the expression of calcium channels, pumps and exchangers located on intracellular calcium storing organelles may alter the nature of the cytosolic calcium response to a range of stimuli. However, while altered store-operated [6,9] and non-stimulated [6] plasmalemmal calcium influx have been linked to the acquisition of a more mesenchymal phenotype in breast cancer cells, changes in calcium channels, pumps and exchangers located on intracellular calcium storing organelles have not been assessed during this process.

A phenotypic conversion and cellular heterogeneity comparable to EMT, which is associated with a remodelling of intracellular calcium homeostasis, is observed in vascular smooth muscle cells [20]. In response to cues from the microenvironment, vascular smooth muscle cells can switch from a contractile to a synthetic (proliferative) phenotype [20]. Vascular smooth muscle cell switching is associated with changes in the expression of ER calcium channels and pumps, including reduced expression of RYR3 and SERCA2a [20,21]. Vascular smooth muscle cells are therefore one example of how intracellular calcium channels and pumps may be remodelled to meet the cellular requirements of specific phenotypes.

In this study we assessed whether alterations in mRNA levels of Golgi, mitochondrial and ER calcium channels, pumps and exchangers were associated with EGF-induced EMT in MDA-MB-468 breast cancer cells.

\section{Results and discussion}

\section{EGF-induced EMT in MDA-MB-468 cells}

MDA-MB-468 breast cancer cells treated with EGF (50 $\mathrm{ng} / \mathrm{mL}$ ) for 3,6 or $12 \mathrm{~h}$ showed a significant increase in mRNA levels of Twist (Figure 1A), a nuclear transcription factor and marker of EMT [22]. This early EMT event was followed by an increase in vimentin mRNA at $12 \mathrm{~h}$ post-EGF treatment (Figure 1B). These findings were consistent with previous studies using this model of EGF-induced EMT [5-8]. We assessed gene expression of calcium channels, pumps and exchangers located on the Golgi, mitochondria and ER with EMT after treatment with EGF for $12 \mathrm{~h}$.

\section{Golgi: SPCA1 and SPCA2}

SPCAs are regulators of Golgi luminal calcium levels [23]. Recently, we showed that SPCA1 is enriched in basal-like breast cancers, a class of aggressive breast cancers with EMT-like features [24]. Given the potential for SPCAs to regulate processes important for carcinogenesis $[24,25]$ and the observed repositioning of the Golgi, in some cell types, to the leading edge during cell migration [26], we hypothesised that altered Golgi calcium homeostasis may be a feature of EGF-induced EMT. However, no significant alterations in the levels of
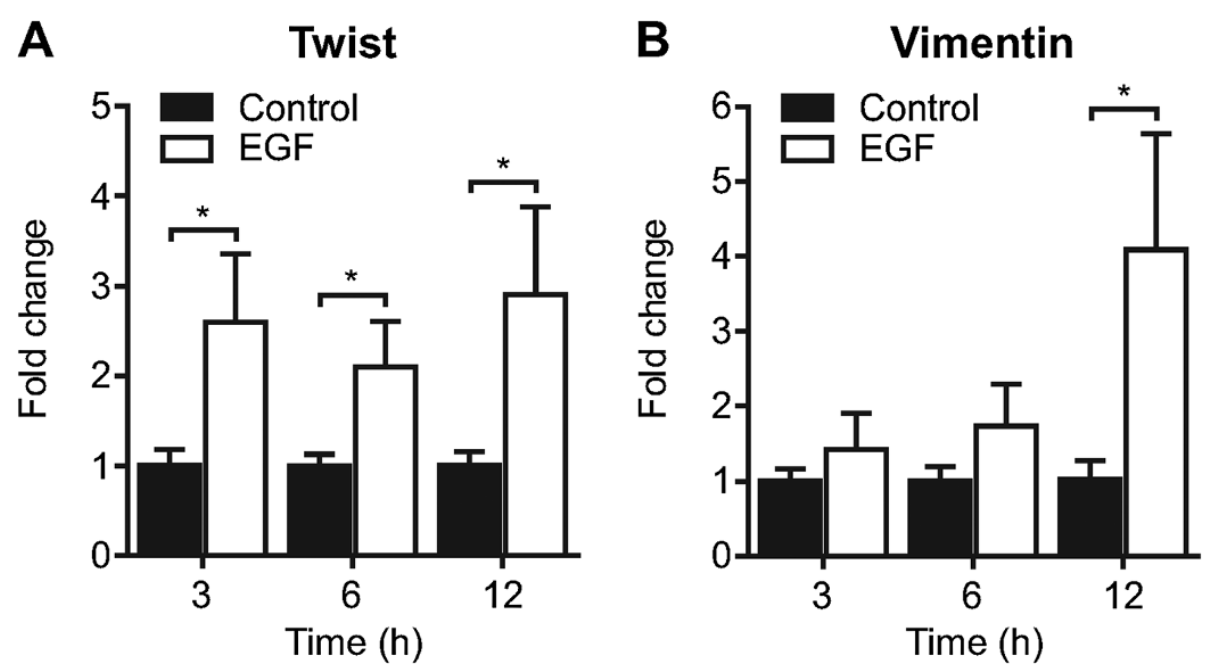

Figure 1 EGF-induced EMT in MDA-MB-468 breast cancer cells. MDA-MB-468 breast cancer cells were serum starved and treated with EGF $(50 \mathrm{ng} / \mathrm{mL})$ as indicated to induce EMT. A) Twist and B) vimentin mRNA expression were assessed using real time RT-PCR at 3,6 and $12 \mathrm{~h}$ following EGF treatment. Bar graphs show mean \pm S.D. for nine individual wells from three independent experiments. The effect of EGF at each time point was assessed using two-way ANOVA with Bonferroni's multiple comparisons post-tests. ${ }^{*} P<0.05$. 
SPCA1 mRNA (Figure 2A) or its related isoform SPCA2 (Figure 2B) were associated with EGF-induced EMT in MDA-MB-468 breast cancer cells.

\section{Mitochondria: MCU and NCLX}

Excess mitochondrial calcium accumulation is a trigger for cell death [27]. Downregulation of the MCU in HeLa cervical cancer cells by miR-25 protects cells from calcium-dependent apoptosis, and reduced expression of $\mathrm{MCU}$ is a feature of poorly differentiated colonic adenocarcinomas [28]. In contrast, MCU expression appears to be enriched in some breast cancer subtypes associated

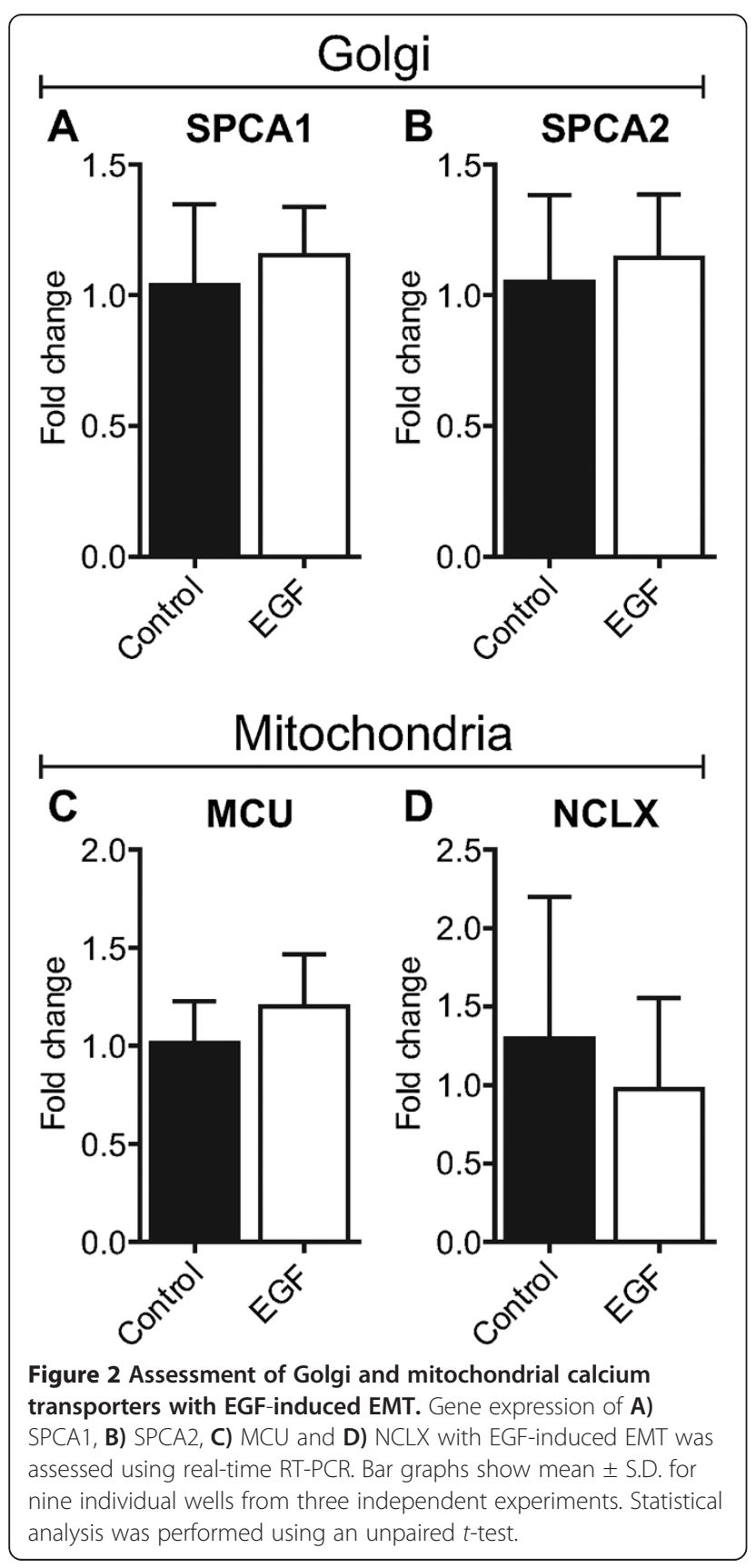

with a poor clinical prognosis [29]. Although several studies have reported that EMT or expression of EMTassociated transcription factors is associated with apoptosis resistance [30-32], the mechanism underpinning this process has not been characterised. We evaluated changes in gene expression of two key mitochondrial calcium accumulation and release proteins-the $\mathrm{MCU}$ [33,34] and NCLX [35] - in breast cancer cells induced to undergo EMT with EGF. Our results show no significant changes in the expression of the MCU or NCLX with EGF-induced EMT in MDA-MB-468 cells (Figure $2 \mathrm{C} \& \mathrm{D}$ ). These findings indicate that if EGFinduced EMT in breast cancer cells is associated with apoptosis-resistance, it is not due to altered gene expression of the MCU or NCLX, at least under these study conditions.

\section{Endoplasmic reticulum: SERCAs, IP $\mathrm{Rs}$ and RYRs}

The ER is a major source of releasable calcium in epithelial cells [36]. Luminal ER calcium levels are maintained by SERCA calcium pumps, which are encoded by three genes (ATP2A/SERCA1-3) [37]. Activation of phospholipase C-coupled receptors (e.g., some G-protein coupled receptors) leads to the production of $\mathrm{IP}_{3}$ and subsequent activation of the ER calcium-permeable channels $\mathrm{IP}_{3} \mathrm{R} 1$, $\mathrm{IP}_{3} \mathrm{R} 2$ and $\mathrm{IP}_{3} \mathrm{R} 3$ [38]. The nature of the cytosolic calcium signal evoked by $\mathrm{IP}_{3}$ is highly dependent on the expression profile of $\mathrm{IP}_{3} \mathrm{Rs}$ [39]. For example, in B cells, activation of $\mathrm{IP}_{3} \mathrm{R} 2$ produces regular and sustained calcium oscillations, while $\mathrm{IP}_{3} \mathrm{R} 3$ generates a calcium response that is characterised by a transient cytosolic calcium peak and few oscillatory spikes [39]. $\mathrm{IP}_{3} \mathrm{R}$ subtypes also differ in their sensitivity to $\mathrm{IP}_{3}$ [39]. To assess possible alterations in ER calcium handling, we assessed both SERCA and $\mathrm{IP}_{3} \mathrm{R}$ isoform mRNA levels in MDAMB-468 breast cancer cells induced to undergo EMT. No significant change in SERCA1 gene expression was observed (Figure 3A). However, an increase in SERCA2 and a down-regulation of SERCA3 was associated with EGF-induced EMT (Figure 3B \& C). EGF-induced EMT was also associated with a 2.5 -fold increase in $\mathrm{IP}_{3} \mathrm{R} 1$ and a 2.2-fold increase in $\mathrm{IP}_{3} \mathrm{R} 3 \mathrm{mRNA}$ levels (Figure $3 \mathrm{D}-\mathrm{F}$ ). Changes in gene expression of SERCA2, SERCA3, IP ${ }_{3} \mathrm{R} 1$ and $\mathrm{IP}_{3} \mathrm{R} 3$ suggest that alterations in ER calcium homeostasis may be a characterising feature of EGF-induced EMT in MDA-MB-468 breast cancer cells.

To determine whether alterations in ER calcium signalling with EMT could also be mediated via alterations in the ryanodine receptor family of (sarco)-endoplasmic reticulum calcium release channels, mRNA levels of ryanodine receptor isoforms were assessed during EGFinduced EMT. There are three ryanodine receptor isoforms in humans; RYR1 is predominantly expressed skeletal muscle; RYR2 is the abundant isoform in cardiac 


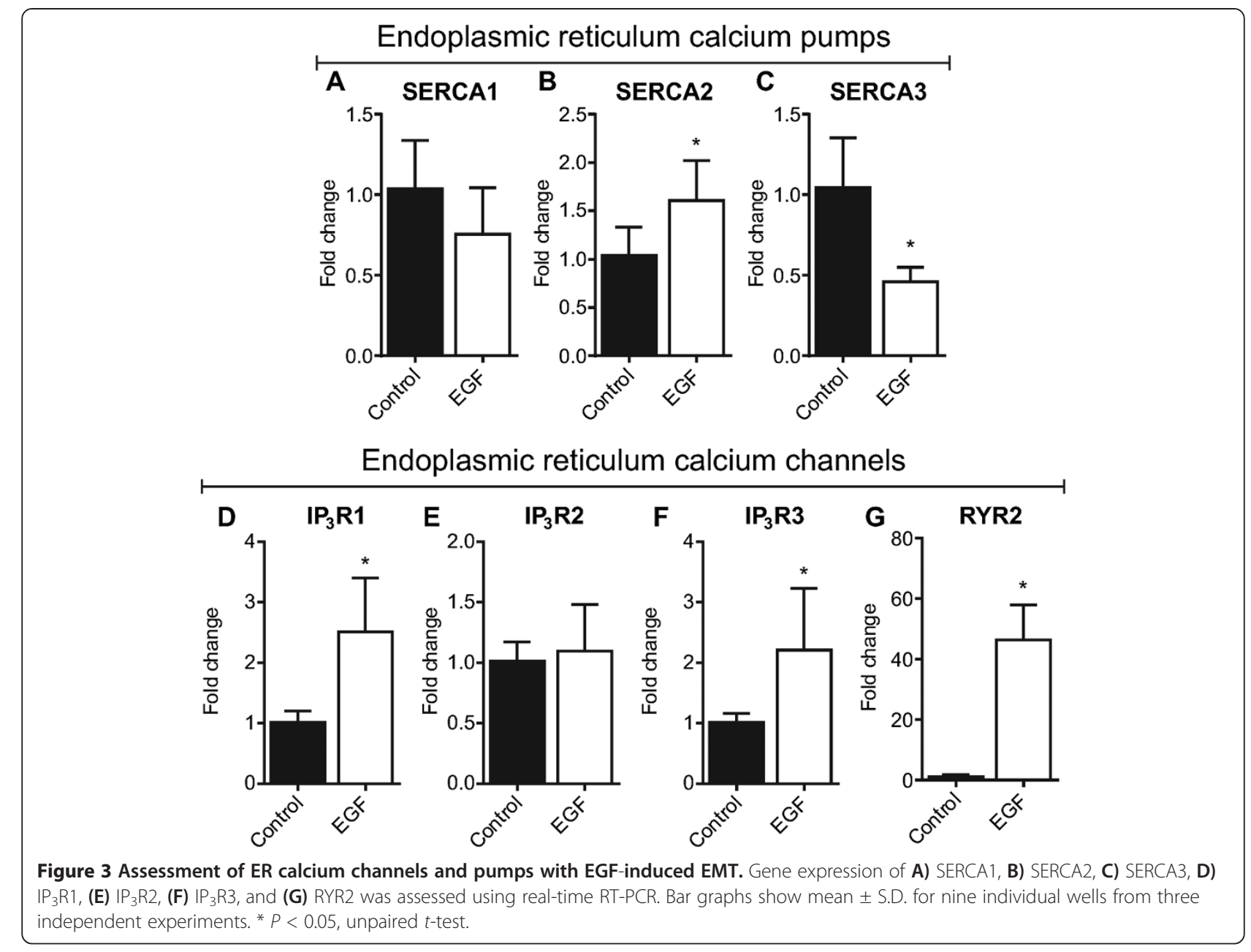

muscle; and RYR3 expression occurs in various tissues including the brain [40]. RYR1 and RYR3 were not detected in MDA-MB-468 epithelial breast cancer cells and expression of these isoforms was not induced to detectable levels with EGF-induced EMT (data not shown). Levels of mRNA for the RYR2 subtype were low in MDA-MB-468 breast cancer cells prior to EMT induction with EGF. However, EGF-treatment induced a marked (46-fold) increase in levels of RYR2 mRNA (Figure 3G). We were unable to detect RYR2 expression in MDA-MB-468 breast cancer cells with immunoblotting using a commercially available antibody (Abcam C3-33, data not shown); however, corresponding to the increase in RYR2 gene expression, MDA-MB-468 breast cancer cells with a more mesenchymal phenotype exhibited a modest but significantly greater response to the ryanodine receptor activator caffeine, as assessed through caffeine-mediated increases in $\left[\mathrm{Ca}^{2+}\right]_{\mathrm{CYT}}$ (Figure $4 \mathrm{~A} \& \mathrm{~B}$ ).

\section{Conclusions}

Alterations in the expression of ER calcium channels and pumps occur in cancer cell lines and clinical cancer samples [12,41-45]. For example, expression of SERCA3 is significantly reduced in colon carcinomas and colon cancer cell lines compared to normal colonic epithelia [41], and SERCA3 expression is elevated with chemically-induced differentiation of colon, gastric and lung cancer cell lines [41,42]. Therefore, the reduced SERCA3 mRNA levels observed in this study with EGF-induced EMT may reflect a loss of cellular differentiation congruent with the acquisition of a more stem cell-like phenotype. Future studies are needed to assess whether these changes are related to EMTassociated stemness and to assess the various SERCA transcript variants with EGF-induced EMT. Ryanodine receptor expression, using an antibody that detects all ryanodine receptor isoforms, also correlates with breast cancer tumour grade [43]. Furthermore, the induction of RYR2 expression by factors/conditions known to induce EMT in a variety of cell types (including EGF, TGF $\beta$ [46] and hypoxia [47]), suggests that RYR2 may be a key calcium channel for the mesenchymal cell phenotype. The association between RYR2 and EMT requires further investigation. 


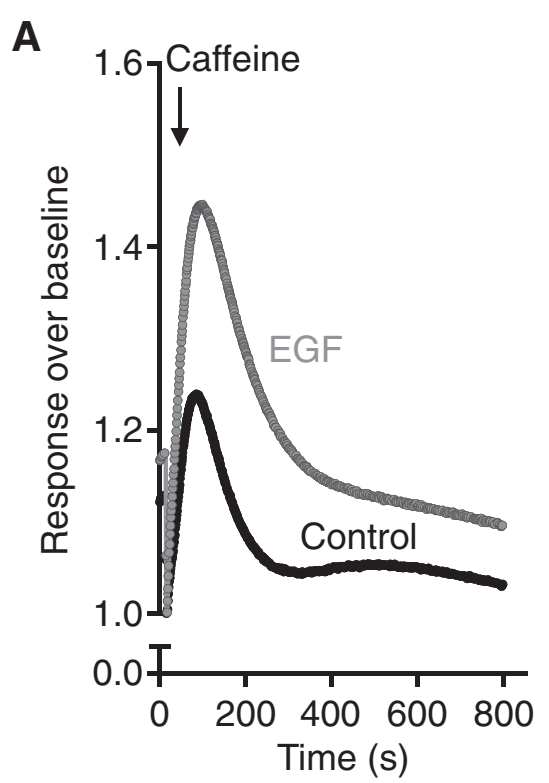

B

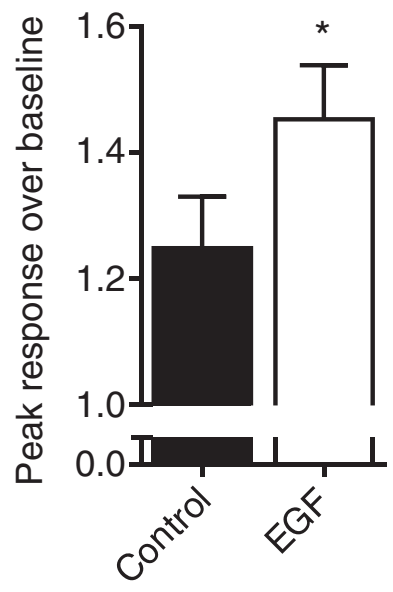

Figure 4 Cytosolic calcium response to caffeine. Assessment of cytosolic calcium responses to $10 \mathrm{mM}$ caffeine in MDA-MB-468 breast cells induced to undergo EMT with EGF (24 h). A) Average response over baseline and B) peak response over baseline. Bar graph shows mean \pm S.D for nine individual wells from three independent experiments. ${ }^{*} P<0.05$, unpaired $t$-test.

We have recently shown that the calcium signal is critically required for EMT induction in breast cancer cells [48] and that, in addition to regulating the conversion to a more mesenchymal cell phenotype, EMT is associated with a remodelling of non-stimulated, agonist-stimulated and store-operated calcium influx [6,7]. This study assessed changes in mRNA levels of intracellular calcium channels, pumps and exchangers with EMT. Our results demonstrate that similar to vascular smooth muscle cell phenotypic switching [20], EMT in breast cancer cells is associated with changes in gene expression of specific ER calcium channels and pumps, the consequence of which may be altered ER calcium storage and signalling. This is in agreement with our previously published data showing altered ER calcium release kinetics with EGF-induced EMT in this cell line [6]. Changes in ER calcium handling may lead to altered responses to phospholipase-C-coupled receptor agonists, and may be important for the invasive properties of mesenchymal-like cancer cells.

\section{Materials and methods}

\section{Cell culture}

MDA-MB-468 cells were maintained in Dulbecco's Modified Eagle's Medium (D6546, Sigma Aldrich) supplemented with penicillin (100 U/mL, Invitrogen), streptomycin (100 $\mu \mathrm{g} / \mathrm{mL}$, Invitrogen), fetal bovine serum (10\%, Sigma Aldrich) and L-glutamine (4 mM, Invitrogen) [6]. To induce EMT, MDA-MB-468 cells were serum-starved $(0.5 \%$ fetal bovine serum) for $24 \mathrm{~h}$ and stimulated with EGF (50 ng/ $\mathrm{mL}$, Sigma Aldrich) for $12 \mathrm{~h}$ (gene expression) or $24 \mathrm{~h}$ (calcium assays) [5-7]. These time points were chosen because changes in mRNA levels are expected to precede changes in functional responses. MDA-MB-468 cells were maintained in a humidified incubator at $37^{\circ} \mathrm{C}$ with $5 \% \mathrm{CO}_{2}$ and routinely tested negative for mycoplasma infection (MycoAlert, Lonza). Short tandem repeat (STR) profiling of the MDA-MB-468 cell line was performed by the Queensland Institute of Medical Research using the StemElite ID Profiling Kit (Promega).

\section{RNA isolation and real-time RT-PCR}

Total RNA was isolated and purified using the RNeasy Plus Mini Kit (Qiagen). RNA (1000 ng) was reverse transcribed using the Omniscript RT Kit (Qiagen) and cDNA amplified using TaqMan Universal PCR Master Mix or TaqMan FAST Universal PCR Master Mix with a StepOnePlus Real Time PCR System (Applied Biosystems). The following Gene Expression Assays (Applied Biosystems) were used in this study: $\mathrm{IP}_{3} \mathrm{R} 1$ (Hs00181881_ $\mathrm{m} 1$ ), IP 3 R2 (Hs00181916_m1), IP 3 R3 (Hs01573555_m1), MCU (Hs00293548_m1), NCLX (Hs00227951_m1), RYR1 (Hs00166991_m1), RYR2 (Hs00892840_m1), RYR3 (Hs0 0168821_m1), SERCA1 (Hs01092295_m1), SERCA2 (Hs 00544877_m1), SERCA3 (Hs00193090_m1), SPCA1 (Hs0 0205122_m1), SPCA2 (Hs00208296_m1), Twist (Hs00361 186_m1) and Vimentin (Hs00185584_m1). Relative quantification was calculated with reference to $18 \mathrm{~S}$ rRNA and analysed using the comparative $C_{T}$ method [49]. Targets registering above the limit of detection or having $C_{T}$ values greater than 35 were assigned a value of 35 . 


\section{FLIPR calcium assays}

Measurement of $\left[\mathrm{Ca}^{2+}\right]_{\mathrm{CYT}}$ responses to caffeine was performed using a fluorometric imaging plate reader (FLIPR ${ }^{\text {TETRA }}$, Molecular Devices) as previously described [24]. Briefly, cells were loaded with Fluo-4 AM $(2 \mu \mathrm{M})$ in a solution containing PBX Signal Enhancer (5\%; PBX No Wash $\mathrm{Ca}^{2+}$ Assay Kit, BD Biosciences) and probenecid $(500 \mu \mathrm{M})$ in physiological salt solution $(\mathrm{KCl} 5.9 \mathrm{mM}$, $\mathrm{MgCl}_{2} 1.4 \mathrm{mM}$, HEPES $10 \mathrm{mM}, \mathrm{NaH}_{2} \mathrm{PO}_{4} 1.2 \mathrm{mM}$, $\mathrm{NaHCO}_{3} 5 \mathrm{mM}, \mathrm{NaCl} 140 \mathrm{mM}$, glucose $11.5 \mathrm{mM}$ and $\mathrm{CaCl}_{2} 1.8 \mathrm{mM}$ ) [6,50]. Calcium measurements were performed with $470 / 95$ and 515/75 nm excitation and emission filters. Fluorescent values were normalised to the point immediately following agonist addition and are expressed as response over baseline.

\section{Statistical analysis}

Statistical analysis was performed using GraphPad Prism (v6.0 for Windows). Statistical tests used in this study are outlined in each figure legend.

\begin{abstract}
Abbreviations
$\left[\mathrm{Ca}^{2+}\right]_{\mathrm{CYT}}$ : Cytosolic calcium concentration; CICR: Calcium-induced calcium release; $C_{T}$ : Cycle threshold; EGF: Epidermal growth factor; EMT: Epithelialmesenchymal transition; ER: Endoplasmic reticulum; FLIPR: Fluorometric imaging plate reader; $\mathbb{P}_{3}$ : Inositol 1,4,5-trisphosphate; $\mathbb{P}_{3} R$ : Inositol 1,4,5trisphosphate receptor; MCU: Mitochondrial calcium uniporter; NCLX: $\mathrm{Na}^{+} / \mathrm{Ca}^{2+}$ Exchanger; PMCA: Plasma membrane calcium ATPase; RTPCR: Reverse transcription polymerase chain reaction; RYR: Ryanodine receptor; SERCA: (sarco)-Endoplasmic reticulum calcium ATPase; SPCA: Secretory pathway calcium ATPase; TRP: Transient receptor potential.
\end{abstract}

\section{Competing interests}

The authors declare that they have no potential conflicts of interest.

\section{Authors' contributions}

Performed the experiments: FD and MP. Designed or conceived the experiments: FD, MP, GM, SRT and EWT. Contributed reagents/materials/ analysis tools: GM and SRT. Wrote the manuscript: FD and GM. Edited the manuscript: SRT, EWT, MP, MOP and PC. All authors read and approved the final manuscript.

\section{Acknowledgements}

This research was partially supported by the National Health and Medical Research Council (NHMRC) [project grants 569645, 1022263 and 1027527] and the National Breast Cancer Foundation (EMPathy National Collaborative Research Program). FD was funded by an NHMRC Biomedical Postgraduate Scholarship [511262]. St. Vincent's Institute received support from the Victorian State Government's Operational Infrastructure Support Program.

\section{Author details}

${ }^{1}$ School of Pharmacy, The University of Queensland, Brisbane, QLD 4072, Australia. ${ }^{2}$ St Vincent's Institute, Fitzroy, VIC 3065, Australia. ${ }^{3}$ Department of Surgery, St. Vincent's Hospital, University of Melbourne, Fitzroy, VIC 3065, Australia.

\section{Received: 9 May 2013 Accepted: 24 July 2013}

Published: 29 July 2013

\section{References}

1. Kalluri R, Weinberg RA: The basics of epithelial-mesenchymal transition. $J$ Clin Invest 2009, 119(6):1420-1428.

2. Mani SA, Guo W, Liao M-J, Eaton EN, Ayyanan A, Zhou AY, Brooks M, Reinhard F, Zhang CC, Shipitsin M, et al: The epithelial-mesenchymal transition generates cells with properties of stem cells. Cell 2008, 133(4):704-715.

3. Nieto MA: The ins and outs of the epithelial to mesenchymal transition in health and disease. Annu Rev Cell Dev Biol 2011, 27:347-376.

4. Creighton CJ, Li X, Landis M, Dixon JM, Neumeister VM, Sjolund A, Rimm DL, Wong H, Rodriguez A, Herschkowitz Jl, et al: Residual breast cancers after conventional therapy display mesenchymal as well as tumorinitiating features. Proc Natl Acad Sci U S A 2009, 106(33):13820-13825.

5. Lo H-W, Hsu S-C, Xia W, Cao X, Shih J-Y, Wei Y, Abbruzzese JL, Hortobagyi GN, Hung M-C: Epidermal growth factor receptor cooperates with signal transducer and activator of transcription 3 to induce epithelial-mesenchymal transition in cancer cells via up-regulation of TWIST gene expression. Cancer Res 2007, 67(19):9066-9076.

6. Davis FM, Peters AA, Grice DM, Cabot PJ, Parat MO, Roberts-Thomson SJ, Monteith GR: Non-stimulated, agonist-stimulated and store-operated Ca2+ influx in MDA-MB-468 breast cancer cells and the effect of EGF-induced EMT on calcium entry. PLOS ONE 2012, 7(5):e36923.

7. Davis FM, Kenny PA, Soo ETL, Van Denderen BJW, Thompson EW, Cabot PJ, Parat M-O, Roberts-Thomson SJ, Monteith GR: Remodeling of purinergic receptor-mediated $\mathrm{Ca}(2+)$ signaling as a consequence of EGF-induced epithelial-mesenchymal transition in breast cancer cells. PLOS ONE 2011, 6(8):e23464.

8. Bonnomet A, Syne L, Brysse A, Feyereisen E, Thompson EW, Noel A, Foidart $J M$, Birembaut $P$, Polette $M$, Gilles C: A dynamic in vivo model of epithelial-to-mesenchymal transitions in circulating tumor cells and metastases of breast cancer. Oncogene 2011, 31:3741-3753.

9. Hu JJ, Qin KH, Zhang Y, Gong JB, Li N, LV D, Xiang R, Tan XY: Downregulation of transcription factor Oct4 induces an epithelial-tomesenchymal transition via enhancement of $\mathrm{Ca}(2+)$ influx in breast cancer cells. Biochem Biophys Res Commun 2011, 411(4):786-791.

10. Berridge MJ, Bootman MD, Roderick HL: Calcium signalling: Dynamics, homeostasis and remodelling. Nat Rev Mol Cell Biol 2003, 4(7):517-529.

11. Monteith GR, McAndrew D, Faddy HM, Roberts-Thomson SJ: Calcium and cancer: targeting $\mathrm{Ca}(2+)$ transport. Nat Rev Cancer 2007, 7(7):519-530

12. Monteith GR, Davis FM, Roberts-Thompson SJ: Calcium channels and pumps in cancer: changes and consequences. J Biol Chem 2012, 287(38):31666-31673.

13. Bootman MD, Collins TJ, Peppiatt CM, Prothero LS, MacKenzie L, De Smet P, Travers M, Tovey SC, Seo JT, Berridge MJ, et al: Calcium signalling-an overview. Semin Cell Dev Biol 2001, 12(1):3-10.

14. Putney JW: The physiological function of store-operated calcium entry. Neurochem Res 2011, 36(7):1157-1165.

15. Endo M: Calcium-induced calcium release in skeletal muscle. Physiol Rev 2009, 89(4):1153-1176.

16. Rizzuto R, Brini M, Murgia M, Pozzan T: Microdomains with high $\mathrm{Ca} 2+$ close to IP3-sensitive channels that are sensed by neighboring mitochondria. Science 1993, 262(5134):744-747.

17. Rizzuto R, Pinton P, Carrington W, Fay FS, Fogarty KE, Lifshitz LM, Tuft RA, Pozzan T: Close contacts with the endoplasmic reticulum as determinants of mitochondrial Ca2+ responses. Science 1998, 280(5370):1763-1766.

18. Csordas G, Thomas AP, Hajnoczky G: Quasi-synaptic calcium signal transmission between endoplasmic reticulum and mitochondria. EMBO J 1999, 18(1):96-108

19. Quintana A, Pasche M, Junker C, Al-Ansary D, Rieger H, Kummerow C, Nunez $L$, Villalobos $C$, Meraner $P$, Becherer $U$, et al: Calcium microdomains at the immunological synapse: how ORAI channels, mitochondria and calcium pumps generate local calcium signals for efficient T-cell activation. EMBO J 2011, 30(19):3895-3912.

20. House SJ, Potier M, Bisaillon J, Singer HA, Trebak M: The non-excitable smooth muscle: Calcium signaling and phenotypic switching during vascular disease. Pflugers Arch 2008, 456(5):769-785.

21. Vallot $\mathrm{O}$, Combettes L, Jourdon P, Inamo J, Marty I, Claret M, Lompre AM: Intracellular $\mathrm{Ca}(2+)$ handling in vascular smooth muscle cells is affected by proliferation. Arterioscler Thromb Vasc Biol 2000, 20(5):1225-1235.

22. Yang J, Mani SA, Donaher JL, Ramaswamy S, Itzykson RA, Come C, Savagner P, Gitelman I, Richardson A, Weinberg RA: Twist, a master regulator of morphogenesis, plays an essential role in tumor metastasis. Cell 2004, 117(7):927-939.

23. Wuytack F, Raeymaekers L, Missiaen L: PMR1/SPCA Ca2+ pumps and the role of the Golgi apparatus as a Ca2+ store. Pflugers Arch 2003, 446(2):148-153. 
24. Grice DM, Vetter I, Faddy HM, Kenny PA, Roberts-Thomson SJ, Monteith GR: Golgi calcium pump secretory pathway calcium ATPase 1 (SPCA1) is a key regulator of insulin-like growth factor receptor (IGF1R) processing in the basal-like breast cancer cell line MDA-MB-231. J Biol Chem 2010, 285(48):37458-37466.

25. Feng M, Grice DM, Faddy HM, Nguyen N, Leitch S, Wang Y, Muend S, Kenny PA, Sukumar S, Roberts-Thomson SJ, et al: Store-independent activation of Orai1 by SPCA2 in mammary tumors. Cell 2010, 143(1):84-98.

26. Luxton GW, Gundersen GG: Orientation and function of the nuclear-centrosomal axis during cell migration. Curr Opin Cell Biol 2011, 23(5):579-588

27. Giacomello M, Drago I, Pizzo P, Pozzan T: Mitochondrial Ca2+ as a key regulator of cell life and death. Cell Death Differ 2007, 14(7):1267-1274.

28. Marchi S, Lupini L, Patergnani S, Rimessi A, Missiroli S, Bonora M, Bononi A,

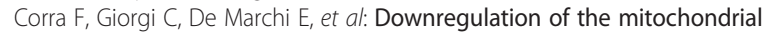
calcium uniporter by cancer-related miR-25. Curr Biol 2013, 23(1):58-63.

29. Curry MC, Peters AA, Kenny PA, Roberts-Thompson SJ, Monteith GR: Mitochondrial calcium uniporter silencing potentiates caspase-independent cell death in MDA-MB-231 breast cancer cells. Biochem Biophys Res Commun. in press.

30. Robson EJ, Khaled WT, Abell K, Watson CJ: Epithelial-to-mesenchymal transition confers resistance to apoptosis in three murine mammary epithelial cell lines. Differentiation 2006, 74(5):254-264.

31. Vega S, Morales AV, Ocana OH, Valdes F, Fabregat I, Nieto MA: Snail blocks the cell cycle and confers resistance to cell death. Genes Dev 2004, 18(10):1131-1143.

32. Vitali R, Mancini C, Cesi V, Tanno B, Mancuso M, Bossi G, Zhang Y, Martinez RV, Calabretta B, Dominici C, et al: Slug (SNAI2) down-regulation by RNA interference facilitates apoptosis and inhibits invasive growth in neuroblastoma preclinical models. Clin Cancer Res 2008, 14(14):4622-4630

33. De Stefani D, Raffaello A, Teardo E, Szabo I, Rizzuto R: A forty-kilodalton protein of the inner membrane is the mitochondrial calcium uniporter. Nature 2011, 476(7360):336-340.

34. Baughman JM, Perocchi F, Girgis HS, Plovanich M, Belcher-Timme CA, Sancak Y, Bao XR, Strittmatter L, Goldberger O, Bogorad RL, et al: Integrative genomics identifies MCU as an essential component of the mitochondrial calcium uniporter. Nature 2011, 476(7360):341-345.

35. Palty R, Silverman WF, Hershfinkel M, Caporale T, Sensi SL, Parnis J, Nolte C, Fishman D, Shoshan-Barmatz V, Herrmann S, et al: NCLX is an essential component of mitochondrial $\mathrm{Na}+/ \mathrm{Ca} 2+$ exchange. Proc Natl Acad Sci U S A 2010, 107(1):436-441.

36. Hetz C, Martinon F, Rodriguez D, Glimcher LH: The unfolded protein response: integrating stress signals through the stress sensor IRE1alpha. Physiol Rev 2011, 91(4):1219-1243.

37. Brini M, Carafoli E: Calcium pumps in health and disease. Physiol Rev 2009, 89(4):1341-1378.

38. Foskett JK, White C, Cheung KH, Mak DO: Inositol trisphosphate receptor Ca2+ release channels. Physiol Rev 2007, 87(2):593-658.

39. Miyakawa T, Maeda A, Yamazawa T, Hirose K, Kurosaki T, lino M: Encoding of $\mathrm{Ca} 2+$ signals by differential expression of IP3 receptor subtypes. EMBO J 1999, 18(5):1303-1308.

40. Marks AR: Intracellular calcium-release channels: regulators of cell life and death. Am J Physiol 1997, 272(2):H597-605.

41. Gelebart P, Kovacs T, Brouland JP, van Gorp R, Grossmann J, Rivard N, Panis $Y$, Martin V, Bredoux R, Enouf J: Expression of endomembrane calcium pumps in colon and gastric cancer cells. Induction of SERCA3 expression during differentiation. J Bio/ Chem 2002, 277(29):26310-26320.

42. Arbabian A, Brouland JP, Apati A, Paszty K, Hegedus L, Enyedi A, Chomienne C, Papp B: Modulation of endoplasmic reticulum calcium pump expression during lung cancer cell differentiation. FEBS J 2012 [Epub ahead of print].

43. Abdul M, Ramlal S, Hoosein N: Ryanodine receptor expression correlates with tumor grade in breast cancer. Pathol Oncol Res 2008, 14(2):157-160.

44. Lee JM, Davis FM, Roberts-Thomson SJ, Monteith GR: lon channels and transporters in cancer. 4 . Remodeling of $\mathrm{Ca}(2+)$ signaling in tumorigenesis: role of $\mathrm{Ca}(2+)$ transport. Am J Physiol Cell Physiol 2011, 30(5):C969-C976.

45. Akl H, Bultynck G: Altered $\mathrm{Ca}(2+)$ signaling in cancer cells: proto-oncogenes and tumor suppressors targeting IP3 receptors. Biochim Biophys Acta 2013, 1835(2):180-193.
46. Awad SS, Lamb HK, Morgan JM, Dunlop W, Gillespie Jl: Differential expression of ryanodine receptor RyR2 mRNA in the non-pregnant and pregnant human myometrium. Biochem J 1997, 322:777-783.

47. Kesherwani V, Agrawal SK: Upregulation of RyR2 in hypoxic/reperfusion injury. J Neurotrauma 2012, 29(6):1255-1265.

48. Davis FM, Azimi I, Faville RA, Peters AA, Jalink K, Putney JW Jr, Goodhill GJ, Thompson EW, Roberts-Thomson SJ, Monteith GR: Induction of epithelial-mesenchymal transition (EMT) in breast cancer cells is calcium signal dependent. Oncogene 2013 [Epub ahead of print].

49. Suchanek KM, May FJ, Robinson JA, Lee WJ, Holman NA, Monteith GR, Roberts-Thompson SJ: Peroxisome proliferator-activated receptor alpha in the human breast cancer cell lines MCF-7 and MDA-MB-231. Mol Carcinog 2002, 34(4):165-171.

50. Vetter I, Touska F, Hess A, Hinsbey R, Sattler S, Lampert A, Sergejeva M, Sharov A, Collins LS, Eberhardt M, et al: Ciguatoxins activate specific cold pain pathways to elicit burning pain from cooling. EMBO J 2012 31(19):3795-3808.

doi:10.1186/1475-2867-13-76

Cite this article as: Davis et al:: Assessment of gene expression of intracellular calcium channels, pumps and exchangers with epidermal growth factor-induced epithelial-mesenchymal transition in a breast cancer cell line. Cancer Cell International 2013 13:76.

\section{Submit your next manuscript to BioMed Central and take full advantage of:}

- Convenient online submission

- Thorough peer review

- No space constraints or color figure charges

- Immediate publication on acceptance

- Inclusion in PubMed, CAS, Scopus and Google Scholar

- Research which is freely available for redistribution

Submit your manuscript at www.biomedcentral.com/submit
C BioMed Central 